\title{
Analisis Yuridis Kebijakan Keuangan Negara dalam Penanganan Pandemi Covid-19 Melalui Peraturan Pemerintah Pengganti Undang- Undang Nomor 1 Tahun 2020
}

\author{
Henny Juliani ${ }^{1}$ \\ Fakultas Hukum, Universitas Diponegoro \\ Jl. Prof. Soedarto, S.H. Tembalang, Semarang \\ Email: hennyjuliani.fhundip@gmail.com
}

\begin{abstract}
COVID-19 pandemic as non-nature disaster due to its impact on health, social, and economy as well, made the President attempted to treat them with public finance policy as implementation of his discretion authority in ruling the government during pandemic. This research was conducted by using empirical juridic approach, focused on analytical descriptive and the result was analyzed qualitatively. The result shows that Perpu No. 1 of 2020 that approved by The House later, represented is a constitutional discretion. In the operational aspect the Government published many regulations to follow up of Perppu Nomor 1 Tahun 2020 that used to resolve emergency condition due to COVID-19, therefore, government officers got immunity in implementing their duties based on goodwill and in accordance with regulations.
\end{abstract}

Keywords: COVID-19, discretion, public finance

\begin{abstract}
Abstrak
Pandemi covid-19 yang berdampak pada bidang kesehatan, sosial, maupun ekonomi sebagai bencana non alam, membawa Presiden untuk melakukan upaya penanganannya dengan kebijakan keuangan negara, sebagai implementasi kewenangan diskresi dalam penyelenggaraan pemerintahan. Penelitian ini menggunakan metode pendekatan yuridis normatif dengan spesifikasi penelitian deskriptif analitis dan hasilnya dianalisis secara kualitatif. Hasil penelitian menampakkan bahwa Perpu Nomor 1 Tahun 2020, yang kemudian disetujui DPR dan menjadi Undang-Undang Nomor 2 Tahun 2020 merupakan diskresi konstitusional. Dalam tataran teknis operasional pemerintah juga mengeluarkan berbagai peraturan kebijakan sebagai tindak lanjut dari Perppu Nomor 1 Tahun 2020 yang digunakan sebagai upaya dalam menangani keadaan genting sebagai akibat pandemi covid19, oleh karena itu pejabat pemerintahan mendapatkan imunitas dalam melaksanakan tugasnya jika didasarkan pada itikad baik dan sesuai dengan ketentuan peraturan perundang-undangan.
\end{abstract}

Kata kunci: COVID-19, diskresi, keuangan negara

1 Dosen Fakultas Hukum Universitas Diponegoro (hennyjuliani.fhundip@gmail.com) 


\section{A. Pendahuluan}

Pasal 4 ayat (1) Undang-Undang Dasar Negara Republik Indonesia Tahun 1945 mengatur bahwa Presiden Republik Indonesia memegang kekuasaan pemerintahan menurut Undang-Undang Dasar. Hal tersebut dimaksudkan bahwa kekuasaan pemerintahan yang dimiliki oleh Presiden Republik Indonesia adalah untuk mencapai tujuan negara dalam menyejahterakan rakyat sebagaimana diamanatkan dalam Pembukaan Undang-Undang Dasar Negara Republik Indonesia Tahun 1945. Tugas Presiden tersebut diatur lebih lanjut dalam Pasal 33 dan 34 yang menjadi dasar pelaksanaan tugas konstitusional negara/pemerintah

Tugas negara/pemerintah dalam mewujudkan kesejahteraan rakyatnya tersebut tidak bisa dilepaskan dari perkembangan kenegaraan dan pemerintahan setelah Perang Dunia II yaitu dengan adanya konsep negara hukum yang baru yang dikenal sebagai konsep negara kesejahteraan (welfare state). Konsep ini menempatkan pemerintah untuk berperan aktif dalam kehidupan sosial ekonomi masyarakatnya dalam mewujudkan kesejahteraan umum (bestuurszorg), di samping tentunya tetap berperan dalam menjaga keamanan dan ketertiban. Oleh karena itu maka peran pemerintah semakin lama semakin luas.

Ridwan HR mengutip pendapat E. Utrecht, yang menyatakan bahwa diberinya tugas "bestuurszorg" itu membawa bagi administrasi negara suatu konsekuensi yang khusus. Agar dapat menjalankan tugas menyelenggarakan kesejahteraan rakyat, menyelenggarakan pengajaran bagi semua warga negara, dan sebagainya secara baik, maka administrasi negara memerlukan kemerdekaan untuk dapat bertindak atas inisiatif sendiri, terutama dalam penyelesaian soal-soal genting yang timbul dengan sekonyong-konyong dan yang peraturan penyelenggaraannya belum ada, yaitu belum dibuat oleh badan-badan kenegaraan yang diserahi fungsi legislatif. $^{2}$

2 Ridwan HR, Hukum Administrasi Negara Edisi Revisi, (Jakarta: Raja Grafindo Persada,2013), halaman 15 
Menurut S.A. de Smith, pemberian kewenangan kepada administrasi negara untuk bertindak atas inisiatif sendiri itu dikenal dengan istilah freies ermessen atau discretionary power, suatu istilah yang di dalamnya mengandung kewajiban dan kekuasaan yang luas. Kewajiban adalah tindakan yang harus dilakukan, sedangkan kekuasaan yang luas itu menyiratkan adanya kebebasan memilih; melakukan atau tidak melakukan tindakan. Dalam praktik antara kewajiban dan kekuasaan berkaitan erat. ${ }^{3}$ Nata Saputra mengartikan freies ermessen sebagai suatu kebebasan yang diberikan kepada alat administrasi, yaitu kebebasan yang pada asasnya memperkenankan alat administrasi negara mengutamakan keefektifan suatu tujuan daripada berpegang teguh kepada ketentuan hukum. ${ }^{4}$

Freies Ermessen atau diskresi dimiliki oleh setiap pemegang jabatan atau pejabat pemerintahan untuk mengambil kebijakan strategis berupa keputusan atau tindakan dalam mengatasi persoalan konkrit yang mendesak yang membutuhkan penanganan segera. Kebijakan pejabat pemerintahan yang diimplementasikan dalam wujud diskresi tersebut dilindungi oleh payung hukum, sehingga setiap pejabat pemerintahan yang melakukan tindakan atas nama jabatannya dan digunakan untuk kepentingan publik akan mendapatkan perlindungan hukum.

Pada awal bulan Maret 2020 Pemerintah Indonesia dihadapkan pada kenyataan bahwa pandemi covid-19 telah menimbulkan korban bagi masyarakat Indonesia, dari waktu ke waktu jumlah korban yang terpapar covid-19 semakin bertambah, semakin membahayakan dan mengancam kesehatan masyarakat. Hal tersebut menimbulkan dampak tidak hanya bagi kesehatan masyarakat, tetapi juga berdampak pada sektor-sektor yang lain, termasuk sektor perekonomian sehingga mendorong pemerintah untuk mengambil tindakan secara cepat, tepat, dan akurat dalam penanganan pandemi covid-19. Langkah-langkah pemerintah dalam penanganan pandemi covid-19 tersebut dilakukan dengan memadukan penggunaan kewenangan peraturan perundang-undangan, peraturan kebijakan, tindakan badan

\footnotetext{
Loc cit
}

Loc cit 
dan pejabat pemerintahan, serta dukungan birokrasi sebagai organ pelaksana kebijakan.

Dalam penanganan pandemi covid-19 Presiden mengambil kebijakan dengan menetapkan Peraturan Pemerintah Pengganti Undang Undang (Perppu) Nomor 1 Tahun 2020 tentang Kebijakan Keuangan Negara dan Stabilitas Sistem Keuangan untuk Penanganan Pandemi Corona Virus Disease (Covid-19) dan/atau Dalam Rangka Menghadapi Ancaman yang Membahayakan Perekonomian Nasional dan/atau Stabilitas Sistem Keuangan pada tanggal 31 Maret 2020. Perppu Nomor 1 Tahun 2020 tersebut ditetapkan sebagai instrumen yuridis dalam penanganan covid-19 karena telah terbukti pandemi covid-19 memberi dampak antara lain terhadap perlambatan pertumbuhan ekonomi nasional, penurunan penerimaan negara, dan peningkatan belanja negara dan pembiayaan. Untuk itu diperlukan upaya pemerintah untuk melakukan penyelamatan kesehatan dan perekonomian nasional, dengan fokus pada belanja untuk kesehatan, jaring pengaman sosial (social safety net), serta pemulihan perekonomian termasuk untuk dunia usaha dan masyarakat yang terdampak.

Sejauh mana kewenangan Presiden menetapkan Perppu Nomor 1 Tahun 2020 sebagai suatu kebijakan keuangan negara dan implikasinya terhadap pelaksanaan Anggaran Pendapatan dan Belanja Negara (APBN)? Berdasarkan halhal tersebut di atas, maka dilakukan penelitian dengan judul: "Analisis Yuridis Kebijakan Keuangan Negara dalam Penanganan Pandemi Covid-19 melalui Perppu Nomor 1 Tahun 2020.”

\section{Metoda Penelitian}

Penelitian ini mengkaji masalah dari sudut pandang hukum dengan menggunakan pendekatan yuridis normatif, karena masalah yang akan diteliti tersebut berhubungan erat dengan law in books, artinya pengungkapan permasalahan yang diteliti berpegang pada ketentuan yang normatif. Spesifikasi penelitian yang digunakan dalam penelitian ini adalah deskriptif analitis, yang selanjutnya bahan-bahan tersebut akan dianalisis secara kualitatif. 


\section{Kerangka Teori}

\section{a. Konsep Diskresi dalam Penyelenggaraan Pemerintahan}

Dalam konsep negara kesejahteraan (welfare state), negara berperan aktif dalam mencampuri kehidupan sosial ekonomi rakyatnya dengan tujuan untuk mewujudkan kesejahteraan rakyatnya. W. Riawan Tjandra mengutip pendapat Asshiddiqie yang menyatakan bahwa bahwa dalam konsep negara kesejahteraan ini, negara dituntut untuk memperluas tanggung jawabnya kepada masalah-masalah sosial ekonomi yang dihadapi rakyat banyak. Perkembangan inilah yang memberikan legalisasi bagi 'negara intervensionis' abad ke 20. Negara justru perlu dan bahkan harus melakukan intervensi dalam berbagai masalah sosial dan ekonomi untuk menjamin terciptanya kesejahteraan bersama dalam masyarakat. Walhasil dengan intervensi ini fungsi negara juga meliputi kegiatan-kegiatan yang sebelumnya berada di luar jangkauan fungsi negara, seperti memperluas ketentuan pelayanan sosial kepada individu dan keluarga dalam hal-hal khusus seperti 'social security', kesehatan, kesejahteraan sosial, pendidikan, dan pelatihan serta perumahan. ${ }^{5}$

Konsep negara kesejahteraan (welfare state), memberikan kewenangan yang luas kepada pemerintah sebagai penyelenggara fungsi pemerintahan yang meliputi fungsi pengaturan, pelayanan, pembangunan, pemberdayaan, dan perlindungan. Sebagai konsekuensi maka pemerintah diberi wewenang untuk mengambil keputusan dan/atau tindakan dalam penyelenggaraan pemerintahan. Kewenangan yang dimiliki pemerintah tersebut menimbulkan hak dan kewajiban yang melekat dalam penyelenggaraan fungsi pemerintahan. Sebagai perwujudannya pemerintah juga diberikan hak kebebasan bertindak (diskresi) dalam penyelenggaraan pemerintahan untuk menghadapi suatu persoalan konkret agar segera diperoleh penyelesaiannya

5 W Riawan Tjandra, Hukum Administrasi Negara, (Yogyakarta: Penerbit Universitas Atma Jaya, 2008), halaman 9. 
Krishna Djaya Darumurti menyatakan bahwa pusat isu teoritiskonseptual dalam menganalisis konsep diskresi adalah tegangan (tension) yang terjadi antara tindakan menjalankan undang-undang (atau peraturan perundangundangan dalam pengertian yang lebih luas) secara legalistik versus tindakan menyimpang dari undang-undang (atau peraturan perundang-undangan dalam pengertian yang lebih luas). ${ }^{6}$ Secara logika, tindakan yang disebut lebih akhir menimbulkan perdebatan tanpa dapat diberikan justifikasi yang memadai. Misal, tindakan tersebut dapat dikualifikasikan secara sumir sebagai pelanggaran hukum; penyalahgunaan kekuasaan karena yang melakukan adalah badan/pejabat pemerintah. Hal ini sejalan dengan penilaian negatif atas konsep diskresi yang dikemukakan oleh Herbert Packer: "The basic trouble with discretion is simply that it is lawless, in the literal sense of that term."7

Menurut B.V. Harris sebagaimana dikutip oleh Krishna, diskresi pada hakikatnya menampakkan satu kecenderungan berupa pengecualian dari keharusan bertindak sesuai aturan umum (general rule) dari peraturan perundang-undangan (pendekatan rule-based atau rule following). Pengecualian tersebut mengandung karakter yang berhubungan erat dengan kebebasan yang disertai dengan ruang lingkup luas secara fungsional berbanding lurus terhadap cakupan dari kekuasaan/kewenangan yang dimiliki oleh badan/pejabat pemerintah. Bahkan lebih jauh lagi ada pandangan yang beranggapan bahwa badan/pejabat pemerintah secara melekat (inheren) memiliki kebebasan bertindak residual tanpa adanya otorisasi undang-undang sekalipun. Pemikiran ini timbul dari asumsi bahwa pemerintah boleh melakukan tindakan apapun sepanjang tidak melanggar hukum atau hak-hak individual. Pandangan ini mengakui bahwa kedudukan pemerintah sama dengan individu yang diandaikan sama-sama memiliki kebebasan dan boleh melakukan apapun sepanjang tidak dilarang oleh hukum. Itu artinya, undangundang atau putusan pengadilan dapat membatasi kebebasan tersebut.

6 Krishna Djaya Darumurti, Diskresi Kajian Teori Hukum, (Yogyakarta: Genta Publishing, 2016), halaman 21.

7 Loc cit 
Sepanjang hal itu tidak dilakukan maka dianggap pemerintah memiliki kebebasan bertindak. Pengertian ini dikonsepsikan sebagai "the third source authority for government action ",

Pengertian diskresi nampak lebih konkret menurut pendapat Charles $\mathrm{H}$. Koch, Jr dalam Krishna, yang menjelaskan lima makna konsep diskresi (administrative discretion), yaitu: individualizing discretion, executing discretion, policy making discretion, unbridled discretion, dan numinous discretion). Menurutnya berdasarkan kriteria tersebut, memungkinkan pengadilan dapat tidaknya menguji tindakan diskresi tersebut. Lebih lanjut Koch, Jr menjelaskan bahwa semangat yang dikandung oleh konsep diskresi adalah untuk memberikan perlindungan bagi pejabat yang menjalankannya berupa ruang kebebasan atau kemungkinan terjadinya kesalahan ketika melakukan tindakan tersebut. ${ }^{9}$

Menurut Sjachran Basah sebagaimana dikutip oleh Ridwan HR, freies ermessen (diskresi) yang diberikan kepada pemerintah atau administrasi negara merupakan konsekuensi logis dari konsepsi welfare state, akan tetapi dalam kerangka negara hukum freies ermessen tidak dapat digunakan tanpa batas. Atas dasar itu Sjachran Basah mengemukakan unsur-unsur freies ermessen dalam suatu negara hukum yaitu: ${ }^{10}$

a. Ditujukan untuk menjalankan tugas-tugas servis publik;

b. Merupakan sikap tindak yang aktif dari administrasi negara;

c. Sikap tindak itu dimungkinkan oleh hukum;

d. Sikap tindak itu diambil atas inisiatif sendiri;

e. Sikap tindak itu dimaksudkan untuk menyelesaikan persoalan-persoalan penting yang timbul secara tiba-tiba;

f. Sikap tindak itu dapat dipertanggungjawabkan baik secara moral kepada Tuhan yang Maha Esa maupun secara hukum.

Penggunaan asas diskresi merupakan sarana bagi aparat pemerintah untuk melakukan terobosan-terobosan serta pemecahan-pemecahan masalah yang membutuhkan penyelesaian yang cepat dan belum ada aturan yang

Ibid, halaman 24

Ibid, halaman 25

10 Ridwan HR, Op cit, halaman 170-171 
mengatur tentang hal tersebut. Konsekuensi yuridis dengan adanya penggunaan diskresi yang tidak didasarkan pada tujuan, peraturan perundang-undangan, dan asas-asas umum pemerintahan yang baik berakibat diskresi tersebut akan mendorong terjadinya tindakan sewenang-wenang dan penyalahgunaan wewenang. Tindakan sewenang-wenang dapat terjadi karena pemerintah tidak cukup memiliki rasionalitas sebagai parameternya. Oleh karena itu, setiap diskresi pemerintah harus didasarkan pada asas legalitas, asas demokrasi, asas tujuan, dan asas-asas umum pemerintahan yang baik sebagai metanorm yang melandasi tindakan pemerintahan. ${ }^{11}$

\section{b. Makna Keadaan Darurat Menurut Peraturan Perundang-undangan}

Menurut Pasal 4 ayat (1) Undang-Undang Dasar Negara Republik Indonesia Tahun 1945 (UUD 1945), "Presiden Republik Indonesia memegang kekuasaan pemerintahan menurut Undang-Undang Dasar." Kekuasaan pemerintahan yang dimiliki tersebut memberikan hak kepada Presiden untuk mengajukan rancangan undang-undang kepada Dewan Perwakilan Rakyat, sebagaimana diatur dalam Pasal 5 ayat (1) UUD 1945.

Di sisi lain Presiden juga diberi kewenangan untuk menetapkan peraturan pemerintah sebagai pengganti undang-undang (Perppu) berdasarkan ketentuan Pasal 22 ayat (1) UUD 1945. Perpu tersebut dapat ditetapkan oleh Presiden dalam hal ihwal kegentingan yang memaksa. Meskipun demikian Perppu ini untuk menjadi undang-undang harus mendapat persetujuan DPR dalam persidangan berikutnya, dan apabila tidak mendapat persetujuan DPR maka Perpu ini harus dicabut. Kewenangan yang dimiliki Presiden tersebut merupakan kewenangan diskresi konstitusional sebagai implementasi dari adanya extraordinary power yang melekat pada Presiden dalam sistem pemerintahan presidensial.

11 Didik Hery Santosa, Penggunaan Asas Diskresi dalam Pengambilan Keputusan, e-Jurnal http://www.bppk.kemenkeu.go.id/publikasi/artikel/418-artikel-soft-competency/23181-penggunaanasas-diskresi-dalam-pengambilan-keputusan 
Mahkamah Konstitusi Republik Indonesia melalui Putusan Nomor 138/PUU-VII/2009 memberikan rumusan tentang syarat adanya kegentingan yang memaksa sehingga Presiden berhak menetapkan Perpu sebagaimana dimaksud Pasal 22 ayat (1) UUD 1945, apabila:

1. Adanya keadaan yaitu kebutuhan mendesak untuk menyelesaikan masalah hukum secara cepat berdasarkan Undang-Undang;

2. Undang-Undang yang dibutuhkan tersebut belum ada sehingga terjadi kekosongan hukum, atau ada Undang-Undang tetapi tidak memadai;

3. Kekosongan hukum tersebut tidak dapat diatasi dengan cara membuat Undang-Undang secara prosedur biasa karena akan memerlukan waktu yang cukup lama sedangkan keadaan yang mendesak tersebut perlu kepastian untuk diselesaikan.

Menurut Mahkamah Konstitusi pengertian kegentingan yang memaksa tidak dimaknai sebatas hanya adanya keadaan bahaya sebagaimana dimaksud oleh Pasal 12 UUD 1945. Dalam pertimbangannya dinyatakan memang benar bahwa keadaan bahaya sebagaimana dimaksud oleh Pasal 12 UUD 1945 dapat menyebabkan proses pembentukan Undang-Undang secara biasa atau normal tidak dapat dilaksanakan, namun keadaan bahaya bukanlah satu-satunya keadaan yang menyebabkan timbulnya kegentingan memaksa sebagaimana dimaksud oleh Pasal 22 ayat (1) UUD 1945.

Jimly Asshiddiqie berpendapat bahwa sebenarnya terdapat dua tipe/jenis Perppu dalam UUD Tahun 1945. Selama ini masyarakat umumnya termasuk para sarjana hukum menganggap hanya ada satu tipe Perppu yang diterbitkan Presiden dalam kegentingan yang memaksa. Dua jenis Perppu yang dimaksud adalah: Pertama, Perppu sebagai undang-undang biasa (negara dalam keadaan normal) yang bersifat sementara karena ada kegentingan yang memaksa dan belum mendapat persetujuan DPR berdasarkan Pasal 22 UUD Tahun 1945. Kedua, Perppu dalam kondisi negara dalam keadaan darurat atau keadaan bahaya berdasarkan Pasal 12 jo Pasal 22 UUD Tahun 1945. Perppu tipe pertama dimaksudkan berlaku permanen sebagai UU biasa. Perppu ini biasanya berisi kebijakan-kebijakan penting untuk segera dituangkan dalam 
bentuk UU, tetapi karena ada kegentingan yang memaksa, tidak tersedia cukup waktu untuk mengajukan, membahas, dan mendapat persetujuan bersama dengan DPR menjadi UU. Perppu tipe kedua, tidak dimaksudkan untuk berlaku permanen, tetapi hanya untuk sementara waktu selama keadaan darurat/bahaya. Perppu tipe kedua ini diterapkan sebagai sarana pemberlakuan negara dalam keadaan darurat sekaligus kebijakan hukum khusus untuk mengatasi dan menanggulangi masalah-masalah yang timbul dalam keadaan bahaya/darurat serta untuk memulihkan keadaan kembali normal. ${ }^{12}$

Selain diskresi konstitusional yang dimiliki oleh Presiden, Pejabat pemerintahan juga memiliki kewenangan diskresi sebagaimana diatur dalam Pasal 1 angka 9 Undang-Undang Nomor 30 Tahun 2014 tentang Administrasi Pemerintahan yang menyatakan bahwa:

"diskresi adalah keputusan dan/atau tindakan yang ditetapkan dan/atau dilakukan oleh Pejabat Pemerintahan untuk mengatasi persoalan konkrit yang dihadapi dalam penyelenggaraan pemerintahan dalam hal peraturan perundangundangan yang memberikan pilihan, tidak mengatur, tidak lengkap atau tidak jelas, dan/atau adanya stagnasi pemerintahan."

Pasal 22 ayat (2) menyatakan bahwa setiap penggunaan diskresi Pejabat

Pemerintahan bertujuan untuk:

a. melancarkan penyelenggaraan pemerintahan;

b. mengisi kekosongan hukum;

c. memberikan kepastian hukum; dan

d. mengatasi stagnasi pemerintahan dalam keadaan tertentu guna kemanfaatan dan kepentingan umum.

Pasal 23 Undang-Undang Nomor 30 Tahun 2014 mengatur tentang lingkup diskresi pejabat pemerintahan yang meliputi:

a. pengambilan Keputusan dan/atau Tindakan berdasarkan ketentuan peraturan perundang-undangan yang memberikan suatu pilihan Keputusan dan/atau Tindakan;

12 https://www.hukumonline.com/berita/baca/lt5eb09bcc9e976/jimly--ada-dua-tipe-perppu-dalamperspektif-konstitusi/ dikutip tanggal 5 Juni 2020, pukul 11.20 
b. pengambilan Keputusan dan/atau Tindakan karena peraturan perundangundangan tidak mengatur;

c. pengambilan Keputusan dan/atau Tindakan karena peraturan perundangundangan tidak lengkap atau tidak jelas; dan

d. pengambilan Keputusan dan/atau Tindakan karena adanya stagnasi pemerintahan guna kepentingan yang lebih luas.

Menurut Pasal 24 Undang-Undang Nomor 30 Tahun 2014, Pejabat

Pemerintahan yang menggunakan diskresi harus memenuhi syarat:

a. sesuai dengan tujuan diskresi sebagaimana dimaksud dalam Pasal 22 ayat (2);

b. tidak bertentangan dengan ketentuan peraturan perundang-undangan;

c. sesuai dengan AUPB;

d. berdasarkan alasan-alasan yang objektif;

e. tidak menimbulkan konflik kepentingan; dan

f. dilakukan dengan iktikad baik.

\section{B. Hasil dan Pembahasan}

\section{Implikasi Pandemi covid-19 terhadap APBN}

Penanganan pandemi covid-19 melalui Perppu Nomor 1 Tahun 2020 sangat diperlukan karena pandemi covid-19 telah membawa implikasi berdampak bagi kesehatan, perekonomian, sosial, dan lain-lain yang pada akhirnya menggerus kesejahteraan rakyat. Dalam Penjelasan Perppu Nomor 1 Tahun 2020 secara singkat antara lain dapat dirumuskan antara lain:

a. Pandemi covid-19 secara nyata telah mengganggu aktivitas ekonomi dan membawa dampak bagi perekonomian sebagian besar negara-negara di seluruh dunia, termasuk Indonesia.

b. Terganggunya aktivitas ekonomi akan berimplikasi pada perubahan dalam postur anggaran (APBN) tahun 2020, baik dari sisi pendapatan negara, belanja negara, maupun pembiayaan.

c. Respon kebijakan keuangan negara dan fiskal dibutuhkan untuk menghadapi risiko pandemi covid-19, antara lain berupa peningkatan belanja untuk mitigasi risiko kesehatan, melindungi masyarakat, dan menjaga aktivitas usaha. Tekanan sektor keuangan berpengaruh pada APBN, terutama sisi pembiayaan.

\section{Langkah-langkah Pemerintah dalam Penanganan Pandemi Covid-19}


a. Presiden mengeluarkan Instruksi Presiden Nomor 4 Tahun 2020 tentang Refocusing Kegiatan, Realokasi Anggaran, Serta Pengadaan Barang dan Jasa dalam Rangka Percepatan Penanganan Corona Virus Disease 2019 (Covid-19) pada tanggal 20 Maret 2020. Hal-hal yang diatur dalam Inpres Nomor 4 Tahun 2020, antara lain:

1). Mengutamakan penggunaan alokasi anggaran yang telah ada untuk kegiatankegiatan yang mempercepat penanganan covid-19 (refocusing kegiatan dan realokasi anggaran) dengan mengacu kepada protokol penanganan covid-19 di Kementerian/Lembaga/Pemerintah Daerah dan rencana operasional percepatan penanganan covid-19 yang ditetapkan oleh Gugus Tugas Percepatan Penanganan Covid-19.

2). Mempercepat refocusing kegiatan dan realokasi anggaran melalui mekanisme revisi anggaran dan segera mengajukan usulan revisi anggaran kepada Menteri Keuangan sesuai kewenangannya.

3). Mempercepat pengadaan barang dan jasa untuk mendukung percepatan penanganan covid-19 dengan mempermudah dan memperluas akses sesuai dengan undang-undang.

Inpres Nomor 4 Tahun 2020 merupakan peraturan kebijakan yang dikeluarkan Presiden dalam penyelenggaraan kewenangan di ranah teknis operasional guna penanganan pandemi covid-19 berkaitan dengan anggaran yang tersedia dalam APBN tahun 2020. Hal ini berkaitan dengan pemenuhan kebutuhan APD, rumah sakit darurat, obat-obatan, biaya-biaya pendukung medis, dan lainlain.

b. Presiden mengeluarkan Perppu Nomor 1 Tahun 2020 tentang Kebijakan Keuangan Negara dan Stabilitas Sistem Keuangan untuk Penanganan Pandemi Corona Virus Disease 2019 (COVID-19) dan/atau dalam Rangka Menghadapi Ancaman yang Membahayakan Perekonomian Nasional dan/atau Stabilitas Sistem Keuangan.

c. Undang-Undang Nomor 2 Tahun 2020 tentang Penetapan Perppu Nomor 1 Tahun 2020 tentang Kebijakan Keuangan Negara dan Stabilitas Sistem Keuangan untuk Penanganan Pandemi Corona Virus Disease 2019 ( COVID-19) dan/atau dalam Rangka Menghadapi Ancaman yang Membahayakan Perekonomian Nasional dan/atau Stabilitas Sistem Keuangan menjadi Undang-Undang dan 
melampirkannya sebagai bagian yang tidak terpisahkan dari Undang-Undang ini. Undang-Undang ini mulai berlaku pada tanggal diundangkan yaitu tanggal $18 \mathrm{Mei}$ 2020.

Pemerintah mengambil kebijakan dan langkah-langkah luar biasa untuk mengatasi dampak sosial ekonomi dari kondisi darurat pandemi covid-19 melalui berbagai kebijakan relaksasi yang berkaitan dengan pelaksanaan APBN, khususnya dengan melakukan peningkatan belanja untuk kesehatan, pengeluaran untuk jaring pengaman sosial (social safety net), dan pemulihan perekonomian, serta memperkuat kewenangan berbagai lembaga dalam sektor keuangan. Pelaksanaan kebijakan keuangan negara dalam penanganan pandemi covid-19 dilakukan dengan perubahan postur dan/atau rincian APBN tahun 2020 yang ditetapkan dengan Undang-Undang Nomor 20 Tahun 2019.

Kebijakan keuangan negara berkaitan dengan kebijakan pendapatan negara termasuk kebijakan di bidang perpajakan, kebijakan belanja negara termasuk kebijakan di bidang keuangan daerah, dan kebijakan pembiayaan.

Kebijakan keuangan negara yang diatur dalam Perppu Nomor 1 Tahun 2020 meliputi:

\section{1) Penganggaran dan pembiayaan}

Dalam rangka pelaksanaan kebijakan keuangan negara, maka berdasarkan Perppu Nomor 1 Tahun 2020 Pemerintah berwenang:

a) menetapkan batasan defisit anggaran, dengan ketentuan sebagai berikut:

1. Melampaui 3\% (tiga persen) dari Produk Domestik Bruto (PDB) selama masa penanganan Corona Virus Disease 2019 (COVID-19) dan/atau untuk menghadapi ancaman yang membahayakan perekonomian nasional dan/atau stabilitas sistem keuangan paling lama sampai dengan berakhirnya Tahun Anggaran 2022;

2. Sejak Tahun Anggaran 2023 besaran defisit akan kembali menjadi paling tinggi sebesar 3\% (tiga persen) dari Produk Domestik Bruto (PDB); dan

3. penyesuaian besaran defisit sebagaimana dimaksud pada angka 1 menjadi sebagaimana dimaksud pada angka 2 dilakukan secara bertahap.

b. melakukan penyesuaian besaran belanja wajib (mandatory spending) sebagaimana diatur dalam ketentuan peraturan perundang-undangan terkait;

c. melakukan pergeseran anggaran antarunit organisasi, antarfungsi, dan / atau antar program ; 
d. melakukan tindakan yang berakibat pengeluaran atas beban Anggaran Pendapatan dan Belanja Negara (APBN), yang anggaran untuk membiayai pengeluaran tersebut belum tersedia atau tidak cukup tersedia, serta menentukan proses dan metode pengadaan barang/jasa;

e. menggunakan anggaran yang bersumber dari:

1. Sisa Anggaran Lebih (SAL);

2. dana abadi dan akumulasi dana abadi pendidikan;

3. dana yang dikuasai negara dengan kriteria tertentu;

4. dana yar,g dikelola oleh Badan Layanan Umum; dan/atau

5. dana yang berasal dari pengurangan Penyertaan Modal Negara pada Badan Usaha Milik Negara (BUMN);

f. menerbitkan Surat Utang Negara dan/atau Surat Berharga Syariah Negara dengan tujuan tertentu khususnya dalam rangka pandemi Corona Virus Disease 2019 (COVID-19) untuk dapat dibeli oleh Bank Indonesia, Badan Usaha Milik Negara (BUMN), investor korporasi, danf atau investor ritel;

g. menetapkan sumber-sumber pembiayaan Anggaran yang berasal dari dalam dan/atau luar negeri;

h. memberikan pinjaman kepada Lembaga Penjamin Simpanan;

i. melakukan pengutamaan penggunaan alokasi anggaran untuk kegiatan tertentu (refocusing), penyesuaian alokasi, dan/atau pemotongan/penundaan penyaluran anggaran Transfer ke Daerah dan Dana Desa, dengan kriteria tertentu;

j. memberikan hibah kepada Pemerintah Daerah; dan/atau

k. melakukan penyederhanaan mekanisme dan simplifikasi dokumen di bidang keuangan negara.

Ketentuan lebih lanjut mengenai kebijakan keuangan negara tersebut, diatur dengan Peraturan Menteri Keuangan, antara lain:

1. PMK No. 33/PMK.010/2020 tentang Tata Cara Pemberian Pinjaman dari Pemerintah kepada Lembaga Penjamin Simpanan

2. PMK Nomor 38/PMK.02/2020 tentang Pelaksanaan Kebijakan Keuangan Negara untuk Penanganan Pandemi Corona Virus Disease (COVID-19) dan/atau Menghadapi Ancaman yang Membahayakan Perekonomian Nasional dan/atau Stabilitas Sistem Keuangan; 
3. PMK No. 46/PMK.07/2020 tentang Pengelolaan Hibah dari Pemerintah Pusat kepada Pemerintah Daerah dalam rangka Penanganan Pandemi Corona Virus Disease 2019 (COVID-19) dan Dampak Akibat Pandemi Corona Virus Disease 2019 (COVID-19).

\section{2) Kebijakan di Bidang Keuangan Daerah}

Dalam rangka pelaksanaan kebijakan di bidang keuangan daerah, Pemerintah Daerah diberikan kewenangan untuk melakukan pengutamaan penggunaan alokasi anggaran untuk kegiatan tertentu (refocusing), perubahan alokasi, dan penggunaan Anggaran Pendapatan dan Belanja Daerah.

\section{3) Kebijakan di Bidang Perpajakan}

Kebijakan di bidang perpajakan antara lain meliputi:

1. penyesuaian tarif Pajak Penghasilan Wajib Pajak badan dalam negeri dan bentuk usaha tetap;

2. perlakuan perpajakan dalam kegiatan Perdagangan Melalui Sistem Elektronik (PMSE);

3. perpanjangan waktu pelaksanaan hak dan pemenuhan kewajiban perpajakan; dan

4. pemberian kewenangan kepada Menteri Keuangan untuk memberikan fasilitas kepabeanan berupa pembebasan atau keringanan bea masuk dalam rangka penanganan kondisi darurat serta pemulihan dan penguatan ekonomi nasional.

Perdagangan Melalui Sistem Elektronik (PMSE) merupakan perdagangan yang transaksinya dilakukan melalui serangkaian perangkat dan prosedur elektronik.

Penyesuaian tarif Pajak Penghasilan Wajib Pajak badan dalam negeri dan bentuk usaha tetap berupa penurunan tarif Pasal 17 ayat (1) huruf b Undang-Undang mengenai Pajak Penghasilan menjadi:

1. sebesar $22 \%$ (dua puluh dua persen) yang berlaku pada Tahun Pajak 2020 dan Tahun Pajak 2021; dan

2. sebesar $20 \%$ (dua puluh persen) yang mulai berlaku pada Tahun Pajak 2022.

\section{4) Pelaksanaan Program Pemulihan Ekonomi Nasional}

Dalam rangka mendukung kebijakan keuangan negara dan guna melakukan penyelamatan ekonomi nasional, Pemerintah menjalankan program pemulihan ekonomi nasional. Program tersebut bertujuan untuk melindungi, mempertahankan dan 
meningkatkan kemampuan ekonomi para pelaku usaha dari sektor riil dan sektor keuangan dalam menjalankan usahanya.

Program pemulihan ekonomi nasional dapat dilaksanakan melalui Penyertaan Modal Negara, penempatan dana dan atau investasi Pemerintah, dan/atau kegiatan penjaminan dengan skema yang ditetapkan oleh Pemerintah. Penyertaan Modal Negara dilakukan melalui Badan Usaha Milik Negara (BUMN) yang ditunjuk. Penempatan dana dan/atau investasi Pemerintah dapat dilakukan langsung oleh Pemerintah dan/atau melalui lembaga keuangan, manajer investasi, dan/atau lembaga lain yang ditunjuk. Skema penjaminan dapat dijalankan langsung oleh Pemerintah dan/atau melalui satu atau beberapa badan usaha penjaminan yang ditunjuk. Pelaksanaan program pemulihan ekonomi nasional diatur lebih lanjut dengan Peraturan Pemerintah, yaitu Peraturan Pemerintah Nomor 23 Tahun 2020.

\section{5) Pelaksanaan Kebijakan Keuangan Negara}

Pelaksanaan kebijakan keuangan negara dan langkah-langkah sebagaimana dimaksud dalam Pasal 2 sampai dengan Pasal 11 dilakukan dengan tetap memperhatikan tata kelola yang baik.

Perubahan postur dan/atau rincian Anggaran Pendapatan dan Belanja Negara (APBN) dalam rangka pelaksanaan kebijakan keuangan negara dan langkah-langkah sebagaimana dimaksud dalam Pasal 2 sampai dengan Pasal 11 diatur dengan atau berdasarkan Peraturan Presiden, yaitu dengan Peraturan Presiden Nomor 54 Tahun 2020.

6) Pelaporan

Penggunaan anggaran dalam rangka pelaksanaan kebijakan keuangan negara dan langkah-langkah sebagaimana dimaksud dalam Pasal 2 sampai dengan Pasal 12 Perppu Nomor 1 Tahun 2020 dilaporkan Pemerintah dalam Laporan Keuangan Pemerintah Pusat.

Dalam Ketentuan Penutup Perppu Nomor 1 Tahun 2020, Pasal 27 ayat (1) dinyatakan bahwa biaya yang telah dikeluarkan Pemerintah dan/atau lembaga anggota KSSK dalam rangka pelaksanaan kebijakan pendapatan negara termasuk kebijakan di bidang perpajakan, kebijakan belanja negara termasuk kebijakan di bidang keuangan daerah, kebijakan pembiayaan, kebijakan stabilitas sistem keuangan, dan program 
pemulihan ekonomi nasional, merupakan bagian dari biaya ekonomi untuk penyelamatan perekonomian dari krisis dan bukan merupakan kerugian negara. Ayat (2) selanjutnya menyatakan bahwa anggota KSSK, sekretaris KSSK, anggota sekretariat KSSK, dan pejabat atau pegawai Kementerian Keuangan, Bank Indonesia, Otoritas Jasa Keuangan, serta Lembaga Penjamin Simpanan, dan Pejabat lainnya, yang berkaitan dengan pelaksanaan Peraturan Pemerintah Pengganti Undang-Undang ini, tidak dapat dituntut baik secara perdata maupun pidana jika dalam melaksanakan tugas didasarkan pada itikad baik dan sesuai dengan ketentuan peraturan perundangundangan. Ayat (3) selanjutnya menyatakan bahwa segala tindakan teermasuk keputusan yang diambil berdasarkan Peraturan Pemerintah Pengganti Undang-Undang ini bukan merupakan objek gugatan yang dapat diajukan kepada Peradilan Tata Usaha Negara.

Ketentuan Pasal 27 Perppu Nomor 1 Tahun 2020 memberi jaminan kepada pemerintah bahwa segala tindakan dan/atau keputusan yang dikeluarkan dalam penanganan pandemi Covid-19 berkaitan dengan biaya yang dikeluarkan bukan merupakan kerugian negara walaupun berakibat pada hilang atau berkurangnya keuangan negara karena digunakan untuk penyelamatan perekonomian dari krisis. Oleh karena itu juga bukan objek gugatan yang dapat diajukan ke PTUN. Terhadap pejabat pemerintahan yang berkaitan dengan pelaksanaan Perppu Nomor 1 Tahun 2020 tersebut juga tidak dapat dituntut secara perdata maupun pidana jika dalam melaksanakan tugas didasarkan pada itikad baik dan sesuai dengan ketentuan peraturan perundang-undangan. Itikad baik menurut Penjelasan Pasal 24 f Undang-Undang Nomor 30 Tahun 2014 adalah keputusan dan/atau tindakan yang ditetapkan dan/atau dilakukan didasarkan atas motif kejujuran dan berdasarkan AUPB. Adapun AUPB yang dimaksud adalah yang memenuhi rumusan Pasal 10 Undang-Undang Nomor 30 Tahaun 2014 tentang Administrasi Pemerintahan, yaitu:
a. Kepastian hukum;
b. Kemanfaatan;
c. Ketidakberpihakan;
d. Kecermatan;
e. Tidak menyalahgunakan kewenangan;
f. Keterbukaan;
g. Kepentingan umum; dan 
h. Pelayanan yang baik.

Pasal 28 Perpu Nomor 1 Tahun 2020 menyatakan bahwa pada saat Peraturan Pemerintah Pengganti Undang-Undang ini mulai berlaku maka terdapat beberapa ketentuan yang berhubungan dengan kebijakan keuangan negara, antara lain bahwa: 1). Pasal 12 ayat (3) beserta penjelasannya, Pasal 15 ayat (5), Pasal 22 ayat (3), Pasal 23 ayat (1), Pasal 27 ayat (3), dan Pasal 28 ayat (3) dalam Undang-Undang Nomor 17 Tahun 2003 tentang Keuangan Negara (Lembaran Negara Republik Indonesia Tahun 2003 Nomor 47, Tambahan lembaran Negara Republik Indonesia Nomor 4286)

2). Pasal 3 ayat (3) Undang-Undang Nomor 1 Tahun 2004 tentang Perbendaharaan Negara (Lembaran Negara Republik Indonesia Tahun 2004 Nomor 5, Tambahan Lembaran Negara Republik Indonesia Nomor 4355);

3). Pasal 11 ayat (22), Pasal 40, Pasal 42, dan Pasal 46 Undang-Undang Nomor 20 Tahun 2019 tentang Anggaran Pendapatan dan Belanja Negara Tahun Anggaran 2020 (Lembaran Negara Republik Indonesia Tahun 2019 Nomor 198, Tambahan Lembaran Negara Republik Indonesia Nomor 6410),

dinyatakan tidak berlaku sepanjang berkaitan dengan kebijakan keuangan negara untuk penanganan penyebaran Covid-19 dan/atau dalam rangka menghadapi ancaman yang membahayakan perekonomian nasional dan/atau stabilitas sistem keuangan berdasarkan Perppu ini. Oleh karena itu pemerintah dalam hal ini Menteri Keuangan menindaklanjuti dengan mengeluarkan beberapa peraturan yang antara lain sebagai berikut:

1). Peraturan Menteri Keuangan Nomor 39/PMK.02/2020 tentang Tata Cara Revisi Anggaran Tahun Anggaran 2020;

2). Peraturan Menteri Keuangan Nomor 43/PMK.05/2020 tentang Mekanisme Pelaksanaan Anggaran Belanja atas Beban APBN dalam Penanganan Pandemi Covid-19.

Pada dasarnya Perppu Nomor 1 Tahun 2020 merupakan implementasi hak Presiden dalam penggunaan kewenangan diskresi konstitusional untuk penanganan 
pandemi covid-19, yang kemudian disetujui DPR menjadi Undang-Undang Nomor 2 Tahun 2020 dan diundangkan pada tanggal 18 Mei 2020. Dalam penanganan pandemi covid-19 pemerintah juga mengeluarkan berbagai peraturan perundangan antara lain Instruksi Presiden Nomor 4 Tahun 2020 maupun peraturan kebijakan lainnya untuk memperlancar penyelenggaraan kewenangan diskresi Pejabat Pemerintahan pada ranah teknis operasional berkaitan dengan penanganan pandemi covid-19.

\section{Simpulan}

Peraturan Pemerintah Pengganti Undang-Undang (Perppu) merupakan kewenangan diskresi konstitusional sebagai hak Presiden berdasarkan Pasal 22 ayat (1) UUD 1945. Dalam hal ihwal kegentingan yang memaksa berkaitan dengan pandemi covid-19, Presiden telah menetapkan Perppu Nomor 1 Tahun 2020 sebagai produk hukum sebagai bagian dari hierarki peraturan perundang-undangan yang dipadukan dengan peraturan kebijakan sebagai dasar teknis operasional dalam penanganan pandemi covid-19, tentunya didukung oleh birokrasi sebagai pelaksana kebijakan. Diskresi yang dimiliki Presiden dan pejabat pemerintahan merupakan kebijakan strategis yang berupa keputusan dan/atau tindakan dalam mengatasi persoalan konkret yang mendesak yang membutuhkan penanganan segera.

\section{Daftar Pustaka}

Darumurti, Krishna Djaya 2016, Diskresi Kajian Teori Hukum, (Yogyakarta: Genta Publishing);

HR, Ridwan, 2013, Hukum Administrasi Negara Edisi Revisi, (Jakarta: Raja Grafindo Persada);

Marbun, SF dan Moh. Mahfud MD, 1987, Pokok-pokok Hukum Administrasi Negara,( Yogyakarta: Liberty);

Soemitro, Ronny Hanitijo, 1994, Metodologi Penelitian Hukum dan Yurimetri, (Jakarta: Ghalia Indonesia);

Tjandra, W Riawan, 2008, Hukum Administrasi Negara, (Yogyakarta: Penerbit Universitas Atmajaya);

Undang-Undang Dasar Negara Republik Indonesia Tahun 1945;

Undang-Undang Nomor 17 Tahun 2003 tentang Keuangan Negara;

Undang-Undang Nomor 1 Tahun 2004 tentang Perbendaharaan Negara;

Undang-Undang Nomor 30 Tahun 2014 tentang Administrasi Pemerintahan.

Undang-Undang Nomor 20 Tahun 2019 tentang Anggaran Pendapatan dan Belanja Negara Tahun Anggaran 2020 
Administrative Law \& Governance Journal. Volume 3 Issue 2, June 2020| ISSN. 2621-2781 Online

Santosa, Didik Hery, 2016, Penggunaan Asas Diskresi dalam Pengambilan Keputusan, e-Jurnal http://www.bppk.kemenkeu.go.id/publikasi/artikel/ 418-artikel-softcompetency/23181-penggunaan-asas-diskresi-dalam-pengambilan-keputusan

Jimly Asshiddiqie, Ada Dua Tipe Perppu dalam Perspektif Konstitusi, https://www.hukumonline.com/berita/baca/lt5eb09bcc9e976/jimly--ada-duatipe-perppu-dalam-perspektif-konstitusi/ 